Marquette University

e-Publications@Marquette

$10-1-1991$

\title{
Adam Smith's Influence on Hegel's Philosophical Writings
}

James P. Henderson

John B. Davis

Marquette University, john.davis@marquette.edu

Published version. Journal of the History of Economic Thought, Vol. 13, No. 2 (Fall 1991): 184-204. DOI. (C) 1991 Cambridge University Press. Used with permission. 


\title{
ADAM SMITH'S INFLUENCE ON HEGEL'S PHILOSOPHICAL WRITINGS
}

\author{
BY \\ JAMES P. HENDERSON \\ AND \\ JOHN B. DAVIS
}

\section{INTRODUCTION}

Historians of economics and philosophy have noted Georg Wilhelm Fredrich Hegel's debt to Adam Smith and have suggested that Hegel's analysis of civil society rests on a Smithian foundation. Laurence Dickey recognized that "Hegel's interest in the Scots coincided with the late eighteenth-century German interest in the relationship between socioeconomic processes in history and the development of civil institutions" (Dickey 1987, p. 194). Georg Lukacs emphasized that "it is highly probable that the study of Adam Smith was a turning-point in Hegel's evolution" (Lukacs 1976, p. 172). In his study of The Formation of the Economic Thought of Karl Marx, Ernest Mandel maintained that Marx discovered political economy and its importance to philosophy in his reading of Hegel. Says Mandel:

[Hegel] had been profoundly affected in his youth by economic studies, in particular by the work of Adam Smith; Marx saw the Hegelian system as a veritable philosophy of labor. [Quoting Pierre Naville:] "When he read the Phenomenology of Mind, the Philosophy of Right, and even the Science of Logic, Marx thus not only discovered Hegel but already, through him, was aware of that part of classical political economy which was assimilated and translated into philosophical terms in Hegel's work; so that Marx would not have gone into his systematic criticism of civil society and the state

The authorsare respectively Professor of Economics at Valparaiso University, Valparaiso, Indiana, and Associate Professor of Economics at Marquette University, Milwaukee, Wisconsin. They wish to thank referees Professor Michael Perelman and Professor Elias L. Khalil, and two anonymous referees for their helpful comments. 
according to Hegel if he had not found in the latter's writings certain elements which were still live, such as the theory of needs, the theory of appropriation, or the analysis of the division of labor" (Mandel 1971, pp. 11-12).

Hegel's Jena Lectures of 1803-1806, Jenenser Realphilosophie I and II, reveal that he was indeed using Smith's Wealth of Nations in a manner similar to Marx's later use of it in the Economic and Philosophic Manuscripts. ${ }^{1}$ According to Z. A. Pelczynski, in the 1805-1806 Lectures, "Hegel tries hard to theorize, but although he describes the effects of industrial society on human powers in vivid terms reminiscent of Marx, he is not yet able to produce a systematic theory of civil society, still less to integrate it into a more comprehensive social and political philosophy" (Pelczynski 1984, p. 5).

Yet that Smith's findings continued to influence Hegel's later writings, if less obviously so, is recognized both by Paul Chamley and by Shlomo Avineri. Avineri comments:

Mechanization and industrialization are...the necessary consequences of civil society. Thus civil society reaches its apex - and it is here that Hegel integrates the Smithian model of a free market into his philosophical system, by transforming Smith's 'hidden hand' into dialectical reason working in civil society, unbeknownst to its own members. Self-interest and self-assertion are the motives of activity in civil society; but these can be realized by the individual only through inter-action with others and recognition by them. The mutual dependence of all on all is inherent in every individual's self-oriented action... Adam Smith is thus aufgehoben - both preserved and transcended - into the Hegelian system (Avineri 1972, pp. 146-47; see also Chamley 1965, pp. 252-55).

Mandel also confirms Smith's continuing influence on Hegel in his review of certain elements of the economic content of Hegel's philosophical writings. Hegel's philosophy of labor is introduced in his System of Ethical Life (System der Sittlichkeit), developed to its fullest extent in the Jena Lectures and in the Phenomenology of Mind, then defended critically in the Philosophy of Right and the Science of Logic. The relationship

1. We know that Smith's Wealth of Nations was translated into German soon after it appeared. "One volume of the first German translation (by T. F. Schiller) came out in the same year as the Wealth of Nations itself. Before the 1 (b a second much better translation, translation had passed through three editions; meanwhrough out in 1786 had met with great which the popular philosopher Christian Garbe [sic) 6 translation which Hegel studied in Jena

success, (Palyi 1928, p. 184). It was Garve'silosophie $I$ and II.
and cited in his lectures, Jenenser Realphiloso 
between human need and labor is first touched upon in his System of Ethical Life. In his mature works, this becomes "a real dialectic between need and labor and thus [Hegel] arrived at a twofold definition of labor as alienating and alienated" (Mandel 1976, p. 155). Moreover, this alienation expands into the alienation of whole economic classes, the contradictions between the extremes of poverty and wealth that is characteristic of modern industrial nations. ${ }^{2}$ Thus though Hegel's debt to Smith is most apparent in his early Jena Lectures, it is fair to conclude that Smith's original influence on Hegel is "preserved and transcended" in the mature Hegelian system.

Indeed, Riedel claims that "Hegel's assimilation of the most advanced theories of political economy, as found in the classical British thinkers from James Steuart to Adam Smith and in the Philosophy of Right of 1821 David Ricardo, had no parallel in German idealistic philosophy" (Riedel 1984, p. 108). How Hegel's understanding of Smith developed and how he transformed Smith's thought is central to both an understanding of Hegel's philosophical writing and an appreciation of the extent of Adam Smith's influence outside of Great Britain and outside of economics. Discussion here investigates Hegel's adoption of Smith's thought in the early Jena Lectures and in the later Philosophy of History and Philosophy of Right.

Hegel's first systematic encounter with political economy was his study of Sir James Steuart's Inquiry into the Principles of Political Economy. ${ }^{3}$ As a result of his reading of Steuart, Hegel saw the problem of personal fragmentation, alienation, less in terms of religious structures and more in terms of economic phenomena. Raymond Plant, drawing on the research of Paul Chamley, concludes that Hegel derived three major insights from his reading of Steuart's Inquiry. "First, there was the beginnings of a philosophy of history which enabled him to take up a far more positive attitude towards the development of modern society" (Plant 1980, p. 64). Thus Hegel concluded that the dialectic had relevance beyond logical method, for it was the key to understanding historical processes. For Hegel, history moves dialectically. Next, "from Steuart's theory of the statesman, he derived a very distinctive theory about the role of the state vis-a-vis modern commercial society" (ibid.). Yet, as we shall see, Hegel also found

2. E. Mandel summarizes Hegel's economics and their influence on the development of Marx's thought in Chapter 10 of his The Formation of the Economic Thought of Karl Marx. Others, in addition to Avineri and Plant, who have recognized Marx's debt to Hegel include Roman Rosdolsky (in the preface to his The Making of Marx's "Capital"), Martin Nicolaus (in his foreword to Grundrisse), and R. P. Bcllamy (in his article "Hegelianism" in The New Palgrave). In contrast, Herbert Marcuse (in his Reason and Revolution) fails to see any Smithian influence.

3. Laurence Dickey summarized his own reasons "why James Steuart's views on political economy found such a receptive audience" (Dickey 1987, p. 196; see also pp. 197-99). Michael Perelman suggests that Steuart's discussion of price theory may have contributed to Hegel's dialectical thinking. 
Smith's laissez-faire dictums appropriate. Finally, of particular importance to this study is Hegel's adoption of Steuart's "idea that the development of the exchange economy caused an increase in human freedom and selfdevelopment, but which at the same time yields its own forms of integration" (ibid.). Elsewhere Plant notes that reading Steuart led Hegel to reconsider the problem of personal fragmentation as a consequence of changes in the economic structure rather than religious structures (Plant 1983, p. 23). Furthermore, Dickey concludes that "it is perfectly possible and even probable that Hegel read Smith and Steuart as complements to each other rather than - as the conventional view would have it - as spokesmen for two different antithetical interpretations of the purposes of 'political economy"' (Dickey 1987, p. 199).

Changes in the structure of the economy were also the focus of another writer of the Scottish Enlightenment, Adam Ferguson (1723-1816). Dickcy argues that the influence of this Scottish writer is clear. Yet even here, Smith's thought was at work. Without entangling ourselves in the controversy surrounding Smith's charges of plagiarism, let us merely quote C.R. Fay's comment that "Ferguson, as philosopher, and Millar, as lawyer, looked with interest over the fence at the new plant of political economy, which Adam Smith was raising. By no means economists themselves... they drew on it for occasional illustration" (Fay 1956, p. 91). ${ }^{4}$ Thus Smith's influence on Hegel was, at first, indirect, coming through the writings of Ferguson. While, "the human consequences of the growing differentiation of function and the development of commercial society was not the primary focus of the Scottish historians...it did...strike a deep chord among the German" philosophers (Plant 1983, p. 22). Not only did Hegel draw on Ferguson's work, but, as Ferguson himself had done, Hegel turned to Adam Smith for a better, deeper understanding of modern commercial, industrial society.

\section{SMITHIAN ROOTS IN HEGEL'S EARLY WRITINGS}

Hegel sought to develop a complete philosophical system. Thus he faced the problem of reconciling the world of concrete reality and the ideal world of consciousness, in Hegel's terms the realm of Nature and the realm of Spirit. These are two separate, parallel, and equivalent worlds. While these worlds are separate and distinct, yet they must be reconciled and the burden

4. Smith's charges of plagiarism are examined by W. R. Scolt (1937, pp. 118-20, Rac (1895, pp. 64-65, and most definitively by Viner (1965), pp. 33-37). The charge first appeared in Dugald Stewart's Biographical Memoirof Adam Sing out Adam Ferguson as the author who

no names, but Bonar $(1932$, pp. 68.69
provoked Smith to issue the charge. 
of that reconciliation falls on Spirit. In his Jena Lectures, this reconciliation takes two forms: language and labor. Through language, the "name-giving power," Spirit takes Nature into its possession and, thus "nature is no longer a realm of images internally suspended, having no being. Rather it is the realm of names" (Hegel 1983, p. 89-90).

Adam Smith's opening sentence reveals the role that labor plays in the reconciliation of what Hegel calls Nature and Spirit for "the annual labour of every nation is the fund which originally supplies it with all the necessaries and conveniences of life which it annually consumes" (Smith 1776, p. lvii). Through labor, Spirit wills the transformation of Nature; the ego moves from a passive to an active state molding Nature, subjecting Nature to man's will. Hegel turned to Adam Smith to better comprehend the progressive development of the economy, "civil society," and to better understand the nature of labor, reconciler of Spirit and Nature, in the most advanced center of civil society, Great Britain.

Karl Marx, who was not aware of Hegel's Jena Lectures, is particularly critical of Hegel's comprehension of the multiple roles played by labor. What Marx does recognize is the influence of the classical economists on Hegel's later work: "Hegel's standpoint is that of modern political economy. He grasps labor as the essence of man - as man's essence in the act of proving itself: he sees only the positive, not the negative side of labor. Labor is man's coming-to-be for himself with alienation, or as alienated man" (Marx 1844, p. 177). Because Marxwas unaware of Hegel's Jena Lectures, this observation is mistaken, for there Hegel sees both the positive and the negative side of labor. Hegel drew his grasp of "the positive side of labor" from Smith's book. ${ }^{5}$ In Smith, the expansion of production is dependent upon, driven by the division and specialization of labor. "It is the great multiplication of the productions of all the different arts, in consequence of the division of labour, which occasions in a well-governed society, ...universal opulence..." (Smith 1776, p. 11). His famous pin factory example illustrates the expansionary effects of the division of labor. Not only does the division of labor expand output, but it changes the nature of the work performed by the laborer: "In the way in which [pin making] is now carried on, not only the whole work is a peculiar trade, but it is divided into a number of branches, of which the greater part are likewise peculiar trades" (ibid., p. 4). Smith goes on to describe "about eighteen distinct operations, which, in some

5. Interestingly, both Smith and Hegel employ a quasi-historical approach when examining the impact of labor on early social and economic development. The difference here is that Smith is focusing on the way that labor produces both goods and new social relationshipsthe three economic classes, with their separate claims to a share of the value of those goods. On the other hand, Hegel maintained that human need and the resulting consumption created shortages, forcing man to labor, and laboring changed both social relationships and human nature. 
manufactories, are all performed by distinct hands" (ibid.).

To illustrate how the specialization and division of labor increases productivity, Hegel cites Smith's pin factory example in two different places in the Jena Lectures. First, in his 1803-1804 Lectures, he says that "the division of labor increases the mass of manufactured [objects]; eighteen men work in an English pin factory.... Each has a specific part of the work to do and only that. A single man would perhaps not make 20, could not even make one; those eighteen jobs divided among ten men produce 4000 per day. But from the work of those ten in a group of eighteen there would [come] 48000" (Hegel 1979, p. 248). ${ }^{6}$ And, in his Lectures of 1805-1806, we find this brief marginal note: "Universal labor, division of labor, [labor-] saving. Ten men can make as many pins as a hundred" (Hegel 1983, p. 121).

For Smith and Hegel, the division of labor not only increases output, but has additional positive and negative consequences for man. In his Philosophy of Right, we find Hegel's mature statement of the causes and consequences of the division of labor:

The universal and objective element in work, on the other hand, lies in the abstracting process which effects the subdivision of needs and means and thereby eo ipso subdivides production and brings the division of labour. By this division, the work of the individual becomes less complex, and consequently his skill at his section of the job increases, like his output. At the same time, this abstraction on one man's skills and means of production from another's completes and makes necessary everywhere the dependence of men on one another and their reciprocal relation in the satisfaction of their other needs. Further, the abstraction of one man's production from another's makes work more and more mechanical, until finally man is able to step aside and install machines in his place (Hegel 1942, 198). ${ }^{7}$

How Hegel arrived at this position can be traced back to his treatment of Smith's analysis as it first developed in Hegel's Jena Lectures. On the positive side, the division of labor draws men together, it is the mediation through which man relates to his fellow men. Smith describes the produc-

6. Avineri translates this passage in the following manner: "The particularization of labour multiplies the mass of production; in an English manufacture, 18 people work at the production of a needle; each has a particular and exclusive side of the work to perform; a single person could not produce 120 needles, even not one..." (Avineri 1972, p. 93).

7. In his article on the "division of labour" in The New Palgrave, Peter Groenewegen maintains that "Hegel was one of the first to point out that as the division of labour makes "work more and more mechanical, ...man is able to step aside and install machines in his place," a feature of the process subsequently noted by Babbage, Ure, and developed by Marx (Groenewegen 1987, 1, p. 902). 
tion of a coarse, rough woolen coat which "is the produce of the joint labour of a great multitude of workmen..." to illustrate the point (Smith 1776, p. 11). Smith concluded that "when the division of labour has been thoroughly introduced, the produce of a man's own labour can supply but a very small part of his occasional wants. The far greater part of them are supplied by the produce of other men's labour..." (ibid., p. 259). In Hegel, this concept of labor as mediator, relating man to his fellow men, is expressed in these terms: "Labor is of all and for all, and the enjoyment [of its fruits] is enjoyment by all. Each [one] serves the other and provides help. Only here does the individual have existence, as individual" (Hegel 1983, p. 120).

Even though the division of labor performs this positive, mediating function, it has important negative aspects as well, because "not only the whole work is a peculiar trade, but it is divided into a number of branches, of which the greater part are likewise peculiar trades." This increasing degree of specialization makes work more and more abstract. Within Smith's pin factory, no single worker produces pins, instead "the important business of making a pin is...divided in to about eighteen distinct operations, which, in some manufactories, are all performed by distinct hands" (Smith 1776, p. 4).

Like his German contemporaries, Hegel was familiar with the work of the writers of the Scottish Enlightenment. Hegel's analysis of the increasingly abstract nature of work in a manufacturing environment shows insights which most probably derived, either directly or through the writings of the other Scottish writers, from Smith's pin factory example in the Wealth of Nations. Hegel argued that

since work is performed only [to satisfy] the need as abstract beingfor-itself, the working becomes abstract as well... Each individual because he is an individual here, labors for a need. Yet the content of his labor goes beyond his need; he labors for the needs of many, and so does everyone. Each satisfies the needs of many, and the satisfaction of one's own particular needs is the labor of many others. Since his labor is abstract in this way, he behaves as an abstract I-according to the mode of thinghood-not as an allencompassing Spirit, rich in content, ruling a broad range and being master of it (Hegel 1983, p. 121).

Smith himself was well aware of the dehumanizing consequences of modern factory work. The division and specialization of labor in the factory took a terrible toll on the humanity of the workers. The mind-numbing repetition of "a few simple operations, frequently one or two" renders the worker "as stupid and ignorant as it is possible for a human creature to become" (Smith 1776, p. 734). Thus the worker's "dexterity at his own particular trade seems...to be acquired at the expence of his intellectual, 
social, and martial virtues" (ibid., 735). So great was this evil that government ought to "take some pains to relieve it" (ibid.). For Smith, then, the specialization and division of labor is a two-sided process-increasing the production of things, while debilitating the producer, the worker. It is on this very point that Hegel made his first explicit citation of Adam Smith's Wealth of Nations. In his 1803-04 Lectures, Hegel pointed out not only the abstractness of the work within the factory, but its general dehumanizing consequences as well. Much of the following quote is Hegel's paraphrasing of Smith's commentary on the alienation of the worker.

The division of labor increases the mass of manufactured [objects] [etc. quoted above].... But in the same ratio that the number [of objects] produced rises, the value of labor falls; the labor becomes that much deader, it becomes machine work, the skill of the single laborer is infinitely limited, and the consciousness of the factory laborer is impoverished to the last extreme of dullness; and the coherence of the singular kind of labor with the whole infinite mass of needs is quite unsurveyable (Hegel 1979, p. 248). ${ }^{8}$

In his 1805-1806 Lectures, Hegel again considered the dehumanizing effects of the specialization and division of labor, this time emphasizing that such abstract work turns the worker into an abstraction:" "Man's laboritself becomes entirely mechanical, belonging to a many-sided determinacy. But the more abstract [his labor] becomes, the more he himself is mere abstract activity" (Hegel 1983, p. 121). Thus for Hegel, within the modern factory, "Labor is one's making oneself into a thing" (ibid., p. 103).

Subjecting Smith's thoughts to dialectical analysis led Hegel to conclude that modern man is less independent, less self-sufficient than his primitive ancestors. Though man is now less dependent on nature, he has become more dependent on his fellow men. Yet even as he becomes more productive, the value of his labor declines. The worker "works at an abstract labor; he wins much from nature. But this merely transforms itself into another contingency. He can produce more, but this reduces the value of his labor; and in this he does not emerge from universal [i.e. abstract] relations" (ibid., p. 138).

Next, Hegel showed how alienation in the workplace spills over into the market place. The proliferation of goods and services combined with the division and specialization of labor requires the introduction of money and a monetary system to make the whole system operate. Smith's early

8. An alternative translation of this is found both in Avincri and in Plant.

9. This was a point that was well understood by a number of late 18 th century German philosophers - something they had deduced from the writings of the Scoltish Enlightenment thinkers (See Plant 1983, pp. 17-24). 
chapter, "Of the Origin and Use of Money," caught Hegel's eye. Smith noted that the division of labor left the producers with a surplus of the product they produced, while at the same time a "very small part of a man's wants" was satisfied by the "produce of his own labor" (Smith 1776, p. 22). The result was that "every man...lives by exchanging" (ibid.). However, this creates new problems; for "when the division of labour first began to take place, this power of exchanging must frequently have been very much clogged and embarrassed in its operations" (ibid.). Consequently, money was invented, exchange monetized, and "the society itself grows to be what is properly a commercial society" (ibid.). In his earlier Jena Lectures, Hegel took up Smith's scenario and expanded on it:

This manifold laboring at needs as things must likewise realize their concept, their abstraction; their universal concept must become a thing like them, but one which, qua universal, represents all needs; money is this materially existing concept, the form of unity, or of the possibility of all things needed.... Need and labor, elevated into this universal, then form on their own account a monstrous system of community and mutual interdependence in a great people; a life of a dead body, that moves itself within itself, one which ebbs and flows in its motion blindly, like the elements, and which requires continual strict dominance and taming like a wild beast (Hegel 1979, p. 249).

In his later Jena Lectures, Hegel recognized that modern man's life is contingent both on the desires of others for the things produced at his place of work, as well as others production of the things that he requires. Driven by the relentless search for profits, the capitalist system expands man's actual needs; at the same time, it creates false needs, while failing to satisfy these genuine human needs. "Needs are thereby diversified; each individual need is subdivided into several; taste becomes refined, leading to further distinction. (In the production of goods a degree of) preparation is demanded which makes the consumable thing ever easier to use. And so that all the individual's incongruous aspects are provided for (e.g. cork, corkscrew, candlesnuffer), he is cultivated as naturally enjoying them" (Hegel 1983, p. 139). The production of these goods, to satisfy man's growing needs, as well as the creation of false needs; leads to further specialization and division of labor. At the same time, it also makes labor more alienating. Again, the influence of Smith's commentary on the dehumanizing effects of the division and specialization of labor is clearly seen in Hegel's remarks.

By the same token, however, he becomes - through the abstractness of labor-more mechanical, duller, spiritless. The spiritual element, this fulfilled self-conscious life, becomes an empty doing. 
The power of the Self consists in a rich (all-embracing) comprehension; this power is lost. He can leave some work to the machine, but his own activity thereby becomes more formalized. His dull work constricts him to a single point, his work becomes more consummate the more one-sided it becomes (ibid.).

Moreover, the specialized modern worker is exposed to three new threats which were of little or no concern prior to this division of labor - the threat of changing fashion, the threat of new technology, and the threat of uncontrollable events in foreign countries.

In his later Jena Lectures, Hegel began by examining the effects of changing fashion on the workers and their livelihood. Here he was elaborating on Smith's analysis, in his chapter "On the Natural and Market Price of Commodities," of the effects of price fluctuations on "the component parts of price." There Smith had written: "The occasional and temporary fluctuations in the market price of any commodity fall chiefly on those parts of its price which resolves itself into wages and profit" (Smith 1776, p. 59). An unanticipated increase in the demand for some goods "augments the profits of the merchants" but "has no effect upon the wages of the weavers" (ibid.). An unexpected decrease in demand not only "reduces the profits of the merchants.... It sinks too the wages of the workmen" (ibid.). Smith expanded on this issue in "Of the Produce of Land which always affords Rent," Part I, of his chapter "Of the Rent of Land." Improved agricultural productivity releases labor from that sector, and Smith explored the diversion of workers into a rapidly expanding production of luxury goods. He also observed that "the poor, in order to obtain food, exert themselves to gratify those fancies of the rich, and to obtain it more certainly, they vie with one another in the cheapness and perfection of their work" (ibid., p. 164).

As he explored this in more depth, Smith discovered that the production of these luxury goods, "the fossils and minerals contained in the bowels of the earth, the precious metals, and the precious stones," for the rich, is fundamentally different from the production of other goods. Here scarcity dominates over abundance, so that production may be reduced or halted to meet the desires of the wealthy. "With the greater part of rich people, the chief enjoyment of riches consists in the parade of riches" (ibid., p. 172). For the rich the "merit" of any luxury good "is greatly enhanced by its scarcity, or by the great labour which it requires to collect any considerable quantity of it, a labour which nobody can afford to pay but themselves" (ibid.). Such rare luxury goods bear the "decisive marks of opulence" which identified their owners as particularly wealthy. The drive to expand production for profit, perverts production for genuine human need. Expanding on Smith's commentary, Hegel, in his Jenenser Realphilosophie II, foresees the perversions of modern marketing, planned obsolescence, the fads and fetishes 
which burst on the scene with increasing frequency, and the like.

Yet this multiplicity creates fashion, mutability, freedom in the use of forms. These things - the cut of clothing, style of furniture - are not permanent. Their change is essential and rational, far more rational than staying with one fashion and wanting to assert something as fixed in such individual forms. The beautiful is subject to no fashion; but here there is no free beauty, only charming beauty which is the adornment of another person and relates itself to [yet] another, a beauty aimed at arousing drive, desire, and which thus has a contingency to it (Hegel 1983, p. 139).

Smith noted, however, that changing fashion was not the only circumstance which jeopardized the jobs of workers; in fact the division of labor, itself the source of expanding output, increased production specifically by replacing workers with machine technology. Smith cited "three different circumstances...in consequence of the division of labor" which increased production, the third of which was: "the invention of a great number of machines which facilitate and abridge labour, and enable one man to do the work of many (Smith 1776, p. 7). Note here that the invention and introduction of machinery not only "facilitates" but also "abridges" labor. Machinery improves labors' productivity, but machinery is also laborsaving. Yet what Smith casually referred to as "the abridgement of labor" not only saves labor, but robs some workers (the abridged laborers) of their livelihood. Furthermore, these inventions also simplify labor, reducing the skill required to perform productive tasks. An important consequence of this labor simplifying is the reduction of the skilled workers' high income down to the much lower wages of semi-skilled and unskilled workers. In Hegel's view, this adds to the burdens of labor, has further seriously alienating consequences for the worker. Machine technology replaces skilled labor and renders such workers' skills either less valuable or altogether valueless, thereby destroying the skilled worker's "possibility of sustaining his existence." Moreover,

similar incessant is the search for ways of simplifying labor, inventing other machines, etc. In the individual's skill is the possibility of sustaining his existence. This is subject to all the tangled and complex contingency in the [social] whole. Thus a vast number of people are condemned to a labor that is totally stupefying, unhealthy, unsafe - in workshops, factories, mines, etc.-shrinking their skills. And entire branches of industry, which supported a large class of people, go dry all at once because of [changes in] fashion or a fall in prices due to inventions in other countries, etc. and this huge population is thrown into helpless poverty. (Hegel 1983, pp. 139-140). 
Here we see one more problem faced by the worker, for his job and livelihood are not only dependent on events in his own country, but are also influenced by events in foreign lands as well. Here Hegel is probably elaborating Smith's commentary on the role of exports as a "vent for surplus production." In Hegel's 1803-1804 Jena Lectures, he remarks that division and specialization of labor has turned workers' jobs into "a [matter of] blind dependence, so that some far-off operation often suddenly cuts off the whole labor of a whole class of men who were satisfying their needs by it, and makes it superfluous and useless" (Hegel 1979, p. 248). ${ }^{10}$ The specialized worker thus finds himself, his livelihood, and his job threatened from three sources: changing fashion may render his product obsolete; new technology may "abridge" his labor; and events in foreign countries, such as new inventions or changing tastes, may make his work "redundant and useless." Yet this is not the end of it, for Hegel remarks later that "factories, manufacturing, base their subsistence on the misery of one class" (Hegel 1983 , p. 166). The misery of the working class, for Hegel, is a two-fold phenomena - the alienating, dehumanizing misery of the workplace and the miserable poverty resulting from low income earned at work. Smith, himself, in his chapter entitled, "Of the Expenses of the Sovereign or Commonwealth," gives a vivid description of this second form of misery, the consequences of the unequal distribution of income which arises from private ownership of property: "Wherever there is great property, there is great inequality. For every rich man, there must be at least five hundred poor, and the affluence of the few supposes the indigence of the many" (Smith 1776, p. 670). Notice that Smith's three great original economic classes - labor, capitalist, and landowner - are resolved by private property into only two classes - the few rich and the many poor. A defining institutional characteristic of capitalism is private property. However, Smith saw the unequal distribution of wealth as a potent source of civil disorder: "The affluence of the rich excites the indignation of the poor, who are often driven by want, and prompted by envy, to invade his possessions" (ibid.).

Smith concluded that this unequal distribution is, in fact, the reason that government was originally instituted: "The acquisition of valuable and extensive property, therefore requires the establishment of civil government" (ibid.). Thus in Smith's view, private property, or more accurately the unequal distribution of private property, requires the formation of government. But the unequal distribution of wealth which gives rise to the

10. Avineri and Plant give this alternative translation: "In thus happens that a far-away operation often affects a whole class of people who have hitherto satisfied their needs through it, all of a sudden it limits (their work), makes it redundant and useless" (Avineri 1972, p. 93 and Plant 1983, p. 211). 
need for government, influences the very purpose of government. "Civil government, so far as it is instituted for the security of property, is in reality instituted for the defense of the rich against the poor, or of those who have property against those who have none at all" (ibid., p. 674). This last comment recalls Smith's proposition in his Lectures on Jurisprudence (1766 version): "Till there be property, there can be no government, the very end of which is to secure wealth, and to defend the rich from the poor" (Smith, 1978, p. 404).

Hegel's commentary on the unequal distribution of wealth and income most clearly reflects Smith's analysis of this consequence of private property. Moreover, Hegel recognizes the role played by another, uniquely capitalist.institution, which Smith had also analyzed - the large scale jointstock company. Smith was impressed with the ability of the joint-stock company to attract large financial capital, because of the limited liability aspect of such firms (see Smith 1776, pp. 699-700). Hegel recasts Smith's analysis of the unequal distribution of wealth and income, introducing Smith's comments on the joint-stock company, to identify the role played by such firms in the distribution process. In Hegel's words:

The contrast [between] great wealth and great poverty appears: the poverty for which it becomes impossible to do anything; [the] wealth [which], like any mass, makes itself into a force. The amassing of wealth [occurs] partly by chance, partly through universality, through distribution. [It is] a point of attraction, of a sort which casts its glance far over the universal, drawing [everything] around itself - just as a greater mass attracts smaller ones to itself. To him who hath, to him is given. Acquisition becomes a manysided system, profiting by means or ways that the smaller business cannot employ. In other words, the highest abstraction of labor pervades that many more individual modes and thereby takes on an ever-widening scope. This inequality between wealth and poverty, this need and necessity, lead to the utmost dismemberment of the will, to inner indignation and hatred. This necessity, which is the complete contingency of individual existence, is at the same time its sustaining substance. State power enters and must see to it that each sphere is supported. It goes into [various] means and remedies, seeking new markets abroad, etc., [but] thereby making things all the more difficult for one sphere, to the extent that state power encroaches to the disadvantage of others (Hegel 1983, p. 140).

Further on, Hegel continues and expands on these remarks concerning the growth of government, again clearly drawing on Smith's commentary: 
It is universal wealth and universal necessity.... [This system] condemns a multitude of people to a raw life, to stultification in labor and to poverty - in order to let others amass wealth and [then] to take it from them. The inequality of wealth is accepted if heavy taxes are levied; this lessens envy and averts the fear of distress and robbery. Aristocrats, who pay no taxes, stand in the greatest danger of losing their wealth through violence, since they cannot find reconciliation by sacrificing it (ibid., p. 145).

At the end of this commentary, Hegel adds this curt remark, directly from Smith "The government wastes its wealth, saves nothing" (ibid.).

Using Smith's Wealth of Nations, Hegel discerned the contradictory characteristics of capitalism, most importantly, the negative, alienating aspects of labor in such an economic system. Much of Hegel's commentary in his early Jena Lectures foretells Marx's analysis in his Economic and Philosophic Manuscripts. When we remember how impressed Hegel was with Sir James Steuart's theory of the statesman, and the need for state intervention into the economic sphere; it would be reasonable to conclude that Hegel too would call for government intervention into the economy. Yet, instead, we see the profound impact of Smith's influence on Hegel's thought. For Hegel, the state must minimize its interference into the economic sphere, "civil society." In Hegel's words:

Freedom of Commerce: interference must be as inconspicuous as possible, since commerce is the field of arbitrariness. The appearance of force must be avoided; and one must not attempt to salvage what cannot be saved, but rather employ the suffering classes in other ways. [The state power] is the universal overseer; the individual is merely entrenched in individuality. Commerce is certainly left to its own devices-but with the sacrifice of this generation and the proliferation of poverty, poor-taxes, and institutions. Yet the [social] substance is not only this regulatory law, as the power that sustains individuals. Rather, it is itself productive [of a] great benefit, the benefit of the whole (ibid., p. 140).

Clearly, Hegel is employing Smith's concept of the Invisible Hand. It is Smith's Invisible Hand, guiding each individual's pursuit of his own selfinterest to do what is required in society's best interest, that "is itself productive of a great benefit, the benefit of the whole." Here, for the first time, we find Hegel working toward the concept of the Cunning of Reason, a concept that plays an important role in his later writings, The Philosophy of History and The Philosophy of Right. How, then, is Smith's influence expressed in Hegel's later works? 


\section{SMITH'S INVISIBLE HAND AND HEGEL'S CUNNING OF REASON}

Hegel's Philosophy of Right concerns the progress of Reason or Spirit in society, that is, the domain of objective spirit, and explains the development of law, morality, and ethical life. Since Hegel came to understand the progress of Reason to be a process of self-recognition whereby the objectification of law, morality, and ethical life are discovered to be dimensions of Reason, Smith's conception of the Invisible Hand at work in the market system that brings about a result additional to that involved in individuals' private purposes was attractive to Hegel. Thus, since much of his conception of civil society in the Philosophy of Right emerged from his earlier Jena work in which Smith's thinking was absorbed and developed in Hegel's idealist metaphysics, it is arguable that the notion of the Invisible Hand in some fashion underlies its counterpart in Hegel's work, the Cunning of Reason.

Much of the Philosophy of Right justifies this supposition. In the realm of ethical life (Sittlichkeit), the third and key part of the Philosophy of Right for the consideration of economic life, Hegel focuses in large part on civil society. He characterized it as the sphere of self-interest, premised on a system of needs, whose study in a system of production is the science of political economy (Hegel 1942, paragraph 188. All citations refer to the paragraph numbers in the Knox translation.):

Political economy is the science which starts from this view of needs and labour but then has the task of explaining mass-relationships and mass-movements in their complexity and their qualitative and quantitative character. This is one of the sciences which has arisen out of the conditions of the modern world. Its development affords the interesting spectacle [as in Smith, Say, and Ricardo] of thought working upon the endless mass of details which confront it at the outset and extracting therefrom the simple principles of the thing, the Understanding effective in the Thing and directing it. It is to find reconciliation here to discover in the sphere of needs this show of rationality lying in the thing and effective there (ibid., 189).

The fundamental accomplishment of this science, Hegel asserts, is to demonstrate that rationality of civil society that itself springs from individuals' pursuit of their own self-interest. Thus "in the course of the actual attainment of selfish ends...there is formed a system of complete interdependence, wherein the livelihood, happiness, and legal status of one man is interwoven with the livelihood, happiness and rights of all" (ibid., 183). Hegel, then, shows the imprint of his study of Steuart and Smith, and accordingly derives his basic understanding of civil society from English 
political economy.

Indeed, in a passage reminiscent of Smith's famous remark about the butcher, brewer, and baker in The Wealth of Nations (see Smith 1776, p. 14), Hegel explains the activity of self-interest in terms of a transcendent rationality, in keeping with his own conception of the progressive selfrealization of Reason: "The fact that I must direct my conduct by reference to others introduces here the form of universality. It is from others that I acquire the means of satisfaction and I must accordingly accept their views. At the same time, however, I am compelled to produce means for the satisfaction of others. We play into each other's hands and so hang together. To this extent everything private becomes social" (Hegel, 1942,192A). The emergence of a rationality within the pursuit of individual self-interest, that is, is expressly a matter of each individual's association of self-interest with the interest of others. Self-interest in effect cannot be solely understood in terms of single individuals, since its activity makes other individuals' interests internal to its own expression. In a general system of needs characterized by the science of political economy, this demonstrates the higher purpose inherent in civil society.

Where men are thus dependent on one another and reciprocally related to one another in their work and the satisfaction of their needs, subjective self-seeking turns into a contribution to the satisfaction of the needs of everyone else. That is to say, by a dialectical advance, subjective self-seeking turns into the mediation of the particular through the universal, with the result that each man in earning, producing, and enjoying on his own account is eo ipso producing and earning for the enjoyment of everyone else (ibid., 199).

This might indeed seem to be Hegel's reading of Smith's Invisible Hand account of the unintended effects of the individual's pursuit of self-interest. Smith's argument concludes regarding the self-seeking individual:

He generally, indeed, neither intends to promote the public interest, nor knows how much he is promoting it. By preferring the support of domestic to that of foreign industry, he intends only his own security; and by directing that industry in such a manner as its produce may be of the greatest value, he intends only his own gain, and he is in this, as in many other cases, led by an invisible hand to promote an end which was no part of his intention (Smith 1776, p. 423).

Thus, where for Smith an Invisible Hand is at work in the activity of selfinterest, for Hegel a "dialectical advance" similarly drives the play of selfinterest to a higher result. Accordingly, while Hegel does not employ the 
notion of the Cunning of Reason in the Philosophy of Right, that notion nonetheless seems operative there in a fashion reminiscent of Smith's notion of the Invisible Hand.

Moreover, that the notion of the Cunning of Reason appears earlier in Hegel's writing - in the "Introduction" to The Philosophy of Historysuggests that attention to it in its earlier context may illuminate Hegel's discussion of economic life in the civil society in the Philosophy of Right. The "Introduction" presents Hegel's conception of history as the self-unfolding of Reason as a rational process. The argument involving the Cunning of Reason explains how the "means" of the historical process - the "needs, passions, and interests" that are the "sole springs of action" are drawn into the progressive development of Reason in history (Hegel 1956, p. 20). Prefiguring the thinking of the Philosophy of Right with regard to the treatment of civil society, Hegel asserts that "Nothing...happens, nothing is accomplished, unless the individua's concerned, seek their own satisfaction in the issue" (ibid., p. 23).

Yet though "needs, passions, and interests" are the evident agents of the historical process, their activity presupposes - and obscures - the progress of Reason in history. Though the self-unfolding of Reason only gradually becomes apparent as an increasing consciousness of Reason in history, whose essence, for Hegel, is free development, "[t]he History of the world is none other than the progress of the consciousness of Freedom" (ibid., p. 19). Thus the particular purposes of individuals preoccupy their attention, while Reason works out its development behind struggle and conflict: "It is not the general idea that is implicated in opposition and combat, and that is exposed to danger. It remains in the background, untouched and uninjured. This may be called the cunning of reason-that it sets the passions to work for itself, while that which develops its existence through such impulsion pays the penalty, and suffers the loss" (ibid., p. 33). In addition, then, to the emphasis Hegel develops in the Philosophy of Right, where implicit in the self-interest of individuals is the regard for others, Hegel here emphasizes that the progressive movement of Reason in history brings about a greater condition of freedom generally. Not only is the interplay of self-interest productive of a social harmony in civil society that suggests Smith's conception in The Wealth of Nations, but this good is increasingly realized as the progressive development of freedom in history. This general development of history, then, underlies the development of objective spirit in the domain of social life, adding a theory of history to Smith's Invisible Hand conception of social harmony.

\section{CONCLUSION}

Hegel's notion of a "dialectical advance" whereby individual "subjective 
self-seeking" becomes a "producing and earning for the enjoyment of everyone else" is absent in Smith's account of the Invisible Hand. Yet it is fair to argue that Smith's view is more a matter of Hegelian dialectical development than it initially appears in its Scottish Enlightenment garb since though individuals' self-interests are opposed, the successful pursuit of self-interest requires that the individual transcend the immediacy of own needs to discover what would satisfy another in exchange. Moreover, Hegel's complex concept of transcendence [aufgehoben], which requires both the overcoming and preservation of that which is transcended, also seems to be at work in Smith's Invisible Hand thinking. While the individual must discover and address the self-interest of other individuals in the marketplace, nonetheless it specifically remains a matter of the individual's self-interest to do so. Thus a higher form of sociality emerges via the contradictory activities of self-interested individuals, though that social harmony the Invisible Hand creates still preserves the play of self-interest.

Though Smith's thinking can appear more dialectical than customarily believed, the differences between Smith and Hegel remain significant, and it should not be thought that the Invisible Hand and the Cunning of Reason are essentially the same notion. In the first place, Hegel's famous comment on the violence of Reason's development in history signals his departure from Smith's more complacent late Renaissance thinking: History is "the slaughter-bench at which the happiness of peoples, the wisdom of States, and the virtue of individuals have been victimized" (ibid., p. 21). The Cunning of Reason is not so much a matter of Reason's obscurity in the events of history - a conception that itself does fit well with the Invisible Hand - but a matter of Reason's unhesitating use of the "needs, passions, and interest" as the means by which Reason develops, however irrational its sacrifice of individuals and societies. This, surely, is not part of Smith's vision, since the Invisible Hand harmonizes and reconciles individuals' selfseeking to generate the happiest state of affairs possible. Secondly, Hegel's conception of transcendence treats that which is preserved in the overcoming of a past state of affairs quite differently than does Smith in his related thinking. For Smith, that is, self-seeking preserves the individual integrity of the economic agent; while for Hegel, individuals' "subjective selfseeking" as often as not leads to their destruction. Thirdly, Smith's metaphysical universe is essentially made up of individuals, while Hegel's is constituted by Reason itself. ${ }^{11}$ This difference perhaps provides Hegel a more dynamic conception of history, in contrast to Smith, since the development of Reason is not limited by the necessity of maintaining individuals' in tegrity as agents in economic life. In the Philosophyof Right, finally, Hegel

11. Smith also made reference to the wisdom of Nature, Deity, and higher Being. The authors wish to thank Professor Elias L. Khalil for bringing this to our altcntion. 
sees it necessary to complement civil society in the domain of objective spirit with Reason's manifestation in the State. Even in his defense of free trade, Hegel is not reluctant to set out in initial schematic fashion the prerogatives of State power in the economy:

At the other extreme to freedom of trade and commerce in civil society is public organization to provide for everything and determine everyone's labour.... This interest invokes freedom of trade and commerce against control from above; but the more blindly it sinks into self-seeking aims, the more it requires such control to bring it back to the universal. Control is also necessary to diminish the dangers of upheavals arising from clashing interests and to abbreviate the period in which their tension should be eased through the working of a necessity of which they themselves know nothing (Hegel 1942,236A).

Smith's notion of the limited responsibilities of the state is thus narrower than Hegel's conception of a state as a further fulfillment of Reason than is available in civil society. Accordingly, Hegel's dialectical method again distinguishes his thinking from his Smithian inheritance. Though he learned his political economy in large part from Smith, he incorporated this understanding of alienation and private property within a framework of his own dialectical thinking. The Invisible Hand and the Cunning of Reason thus part ways in substantial fashion, despite their other similarities.

In conclusion it should be appreciated that the nature of Smith's influence on continental philosophy in the nineteenth century has not always been well recognized. Yet a careful review of the development of Hegel's ideas about civil society as they progressed from the Jena Lectures to Hegel's mature writings reveals more fully the extent to which "Adam Smith is thus aufgehoben - both preserved and transcended - into the Hegelian system" [Avineri,op. cit.]. Hegel turned to Smith for a deeper understanding of modern commercial and industrial life as it had progressed in the most economically advanced nation of his time. Subjecting Smith's Wealth of Nations to his own dialectical critique provided Hegel with a broader view of human society - from economy to civil society - and the fundamental forces at work in such a society - from the Invisible Hand to the Cunning of Reason. Smith, then, occupies a more substantial place in nineteenth century continental thought than has generally been believed, though this role, in fundamental ways, departs from what has been traditionally associated with the Wealth of Nations. 


\section{REFERENCES}

Avineri, Shlomo. 1972. Hegel's Theory of the Modern State, Cambridge University Press, Cambridge.

Bellamy, R. P. 1987. "Hegelianism," in The New Palgrave, 2, 635-36, edited by John Eatwell, Murray Milgate and Peter Newman, The Macmillan Press Limited, London.

Bonar, James. 1932. A Catalogue of the Library of Adam Smith, 2nd edition, reprint 1966, Augustus Kelley, New York.

Chamley, Paul. 1963. Economie Politique et Philosophie chez Steuart et Hegel, Dalloz, Paris.

. 1965. "Les Origines de la pensee economique de Hegel," Hegel Studien, Band 3, 225-61.

Dickey, Laurence. 1987. Hegel: Religion, Economics, and the Politics of Spirit, 1770-1807, Cambridge University Press, Cambridge.

Fay, C. R. 1956. Adam Smith and the Scotland of His Day, Cambridge University Press, Cambridge.

Groenewegen, Peter. 1987. "Division of Labour" in The New Palgrave, 1, 901-7, edited by John Eatwell, Murray Milgate and Peter Newman, The Macmillan Press Limited, London.

Hegel, G. W. F. 1956. The Philosophy of History, translated by J. Sibree, Dover Publications, New York.

- 1942. The Philosophy of Right, translated by T. M. Knox, Oxford

University Press, Oxford.

. 1979. "Philosophy of Spirit 1803-04," System of Ethical Life (1802/

3) and First Philosophy of Spirit [Part III of the System of Speculative Philosophy 1803/4], edited and translated by H. S. Harris and T. M. Knox, State University of New York Press, Albany. [Cited as Jenenser Realphilosophie I]. . 1983. "Philosophy of Spirit (1805-06)," Hegel and the Human Spirit, translated by Leo Rauch. Wayne State University Press, Detroit.(Cited as Jenenser Realphilosophie II).

Khalil, Elias L. 1990. "Beyond Self-Interest and Altruism: A Reconstruction of Adam Smith's Theory of Human Conduct," Economics and Philosophy, 6, October, 255-73.

Lukacs, Georg. 1976. The Young Hegel, translated by Rodney Livingstone, The MIT Press, Cambridge, Mass.

Mandel, Ernest. 1971. The Formation of the Economic Thought of Karl Marx, translated by Brian Pearce, Monthly Review Press, New York. Marcuse, Herbert. 1941. Reason and Revolution, Routledge and Kegan Paul, London.

Marx, Karl. 1844. The Economic and Philosophic Manuscripts of 1844, translated by Martin Milligan, International Publishers, New York, 1964. 
Nicolaus, Martin. 1973. "Foreword" to the Grundrisse, Vantage Books, New York.

Palyi, Melchior. 1928. "The Introduction of Adam Smith on the Continent," in Adam Smith, 1776-1926, Lectures to Commemorate the Sesquicentennial of the Publication of "The Wealth of Nations,"180-233, The University of Chicago Press, Chicago.

Pelczynski, Z. A., ed. 1984. The State and Civil Society, Studies in Hegel's Political Philosophy, Cambridge University Press, Cambridge.

Plant, Raymond. 1980. "Economic and Social Integration in Hegel's Political Philosophy," Hegel's Social and Political Thought, 59-90, edited by Donald Phillip Verene, Humanities Press, New Jersey. . 1983. Hegel, An Introduction, 2d edition, Basil Blackwell Publisher Limited, Oxford.

Rae, John. 1895. Life of Adam Smith, reprint, Augustus Kelley, New York, 1965.

Riedel, Manfred. 1984. Between Tradition and Revolution, The Hegelian Transformation of Political Philosophy, Cambridge University Press, Cambridge.

Rosdolsky, Roman. 1977. The Making of Marx's "Capital," Pluto Press Limited, London.

Rubel, Maximilien and Margaret Manale. 1975. Marx without Myth, $A$ Chronological Study of his Life and Work, Harper and Row, New York. Scott, William R. 1937. Adam Smith as Student and Professor, reprint, Augustus Kelley, New York, 1965.

Smith, Adam. 1776. The Wealth of Nations, reprint, The Modern Library, New York, 1937.

. 1978. Lectures on Jurisprudence, edited by R. L. Meek, D. D. Raphael, and P. G. Stein, Oxford University Press, Oxford.

Steuart, Sir James. 1966. An Inquiryinto the Principles of Political Economy, edited by A. Skinner, Oliver and Boyd, London.

Stewart, Dugald. 1793. Biographical Memoir of Adam Smith, reprint, Augustus Kelley, New York, 1966.

Viner, Jacob. 1965. Guide to John Rae's "Life of Adam Smith," Augustus Kelley, New York. 